\title{
KELIMPAHAN DAN KEANEKARAGAMAN FITOPLANKTON DI PERAIRAN PESISIR HOLTEKAMP KOTA JAYAPURA
}

Leonardo Elisa Aisoi ${ }^{*}$

${ }^{1}$ Universitas Cenderawasih, Jl. Abepura-Sentani, Jayapura, 33591, Indonesia

*Corresponding author, e-mail: leon_aisoi@yahoo.com

\section{ABST RACT}

The research on abundance and diversity of phytoplankton has been conducted in the coastal waters of PLTU Holtekamp, Muara Tami district, Jayapura City, Papua Province. The background of this research is environmental was changed and it caused by human activities, PLTU activities, both of derived from organic and inorganic contamination. The purpose of research was to determine the abundance and diversity of phytoplankton in these waters. This research was observation research, namely by taking samples from 3 stations. Sampling was use planktonnet, observe was use microscope, identified, counted, and analyzed plankton diversity index. Identification was carried out at the Zoology Laboratory of the Biology Education Study Program, Department of Mathematics and Science Education, Teacher and Education Faculty, Cenderawasih University. Plankton abundance was calculated using Lackey Drop Micro Transect Counting Method and Plankton diversity was calculated using formulas Shannon-Weaner. The result shows that there were 17 genera of phytoplankton which were dominated by diatoms and dinoflagellates. The highest abundance found in the station 3 is 2655 ind/l. Diversity index $\left(\mathrm{H}^{\prime}\right)$ ranged from 1.73 to 1.90 which indicates that there is unstable ecological conditions and dominance index (C) ranging from 0.24 to 0.28 which indicating there no dominant species.

Keywords: Phytoplankton, Abundance, Diversity Index, Dominance Index

\section{PENDAHULUAN}

Laut merupakan ekosistem yang memiliki keanekaragaman tinggi, dimana biota yang ditemukan pada ekosistem laut bervariasi, seperti alga, kerang, kepiting, ikan, dan berbagai biota mikroskopis (Nontji, 2008). Perairan laut terbagi atas beberapa zona, salah satunya adalah daerah air dangkal seperti pesisir pantai. Secara vertikal pantai masuk dalam zona neritik dan secara horisontal termasuk dalam zona eufotik. Komponen biotik yang ditemukan di dalam ekosistem pantai ada dua macam yaitu autotrofik atau produsen dan heterotrofik atau konsumen. Produsen utama pada perairan pantai adalah fitoplankton (Odum, 1996).

Plankton merupakan biota terkecil yang dapat ditemukan pada perairan laut maupun tawar. Plankton dibedakan menjadi dua jenis, yaitu fitoplankton dan zooplankton. Fitoplankton adalah plankton yang termasuk dalam kelompok tumbuhan dan merupakan produsen primer terbanyak di perairan. juga merupakan penghasil oksigen pada wilayah perairan karena dapat melakukan fotosintesis dan sebagai dasar rantai makanan bagi kehidupan perairan laut serta perairan sungai, fitoplankton juga merupakan salah satu parameter tingkat kesuburan suatu perairan (Sunarto, 2008; Yuliana, dkk., 2012). 
Perubahan kualitas air dapat ditinjau dari kelimpahan dan komposisi fitoplankton di perairan tersebut (Wijaya \& Hariyati, 2011). Fitoplankton merupakan parameter biologi yang dapat dijadikan indikator untuk mengevaluasi kualitas dan tingkat kesuburan suatu perairan (bioindikator) (Yuliana, dkk., 2012).

Pembangkit Listrik Tenaga Uap (PLTU) telah dibangun di sekitar pantai Holtekamp, Kelurahan Koya Barat Distrik Muara Tami, Kota Jayapura, Provinsi Papua. Pembangunan dan pengoperasian PLTU Holtekamp akan memberikan dampak negatif terhadap lingkungan perairan Holtekamp. Hasil peneltian Ikhsan, dkk., (2016) menunjukan bahwa pada stasiun dengan suhu tinggi akibat aktivitas PLTU Cirebon menunjukan kelimpahan plankton yang sangat rendah. PLTU mempunyai produk buangan berupa air panas yang suhunya lebih tinggi daripada suhu air sebelum digunakan sebagai pendingin (Hutomo \& Arinardi, 1992). Menurut Nybakken (1992), pemanfaatan air laut sebagai pendingin dapat berpengaruh terhadap kenaikan suhu air laut juga akan berpengaruh terhadap kadar oksigen, salinitas, dan perubahan $\mathrm{pH}$, dan akan menyebabkan gangguan-gangguan pada komunitas organisme laut, terutama plankton.

Berdasarkan latar belakang tersebut, maka sebelum pengoperasian PLTU, perlu dilakukan studi awal untuk mengetahui kelimpahan dan keanekaragaman fitoplankton di perairan Holtekamp Kota Jayapura.

\section{METODE}

\section{Tempat dan Waktu}

Penelitian ini dilaksanakan pada bulan Februari-Juni 2019 di sekitar perairan PLTU Holtekamp, Kelurahan Koya Barat, Distrik Muara Tami, Kota Jayapura, Provinsi Papua.

\section{Alat dan Bahan}

Bahan yang digunakan dalam pengambilan sampel adalah sampel air laut dan formalin 4\%. Alat yang digunakan yaitu plankton net no. 25, botol sampel, ember, box, mikroskop binokuler, object glass, cover glass, pipet tetes, tisu, Multy Modification Parameter Instrument, GPS, dan buku identifikasi plankton merujuk pada Yamaji (1976) \& Davis (1995),

\section{Penentuan Titik Pengambilan Sampel}

Metode yang digunakan dalam penentuan stasiun sampling adalah "Purposive Sampling" di perairan PLTU Holtekamp. Dalam menentukan titik pengambilan sampel pada penelitian ini batasan yang di terapkan peneliti adalah radius atau jarak keliling dari tempat yang diperkirakan menjadi lokasi pembuangan limbah air panas. Radius yang di tetapkan memiliki diameter sekitar $200 \mathrm{~m}$. Stasiun pengambilan sampel berjumlah tiga stasiun, dengan jarak tiap stasiun sekitar $200 \mathrm{~m}$.

\section{Pengambilan sampel fitoplankton}

Pengambilan sampel fitoplankton di perairan dangkal $(<20$ meter $)$, setiap stasiun dulang sebanyak tiga kali, yaitu pada waktu pagi hari, siang hari, dan sore hari. Pengambilan sampel dilakukan dengan cara mengambil air dengan menggunakan watersampler kapasitas 4,2 liter sebanyak 24 kali (total 100 l) yang disaring dengan planktonet (Fachrul, 2008; Nonji 2008). Sampel air yang tersaring pada botol sampel sebanyak $100 \mathrm{ml}$ untuk setiap ulangan per stasiun, total sampel untuk ketiga stasiun dengan tiga kali ulangan sebanyak $900 \mathrm{ml}$ dan dibawa ke 
laboratrium untuk dianalisis. Sampel plankton yang tersaring di botol penampung dipindahkan ke dalam botol sampel yang telah diberi formalin $4 \%$ dan setiap sampel diberi label sesuai stasiun.

\section{Pengukuran parameter lingkungan}

Pengukuran parameter lingkungan dilakukan pada tiap stasiun sebanyak 3 kali yang dilakukan bersamaan pada saat pengambilan sampel fitoplankton pada pagi, siang, dan sore hari. Adapun paremeter tersebut adalah suhu, kecerahan, $\mathrm{pH}$, Salinitas, DO, Kecepatan arus, phospat, dan Nitrat.

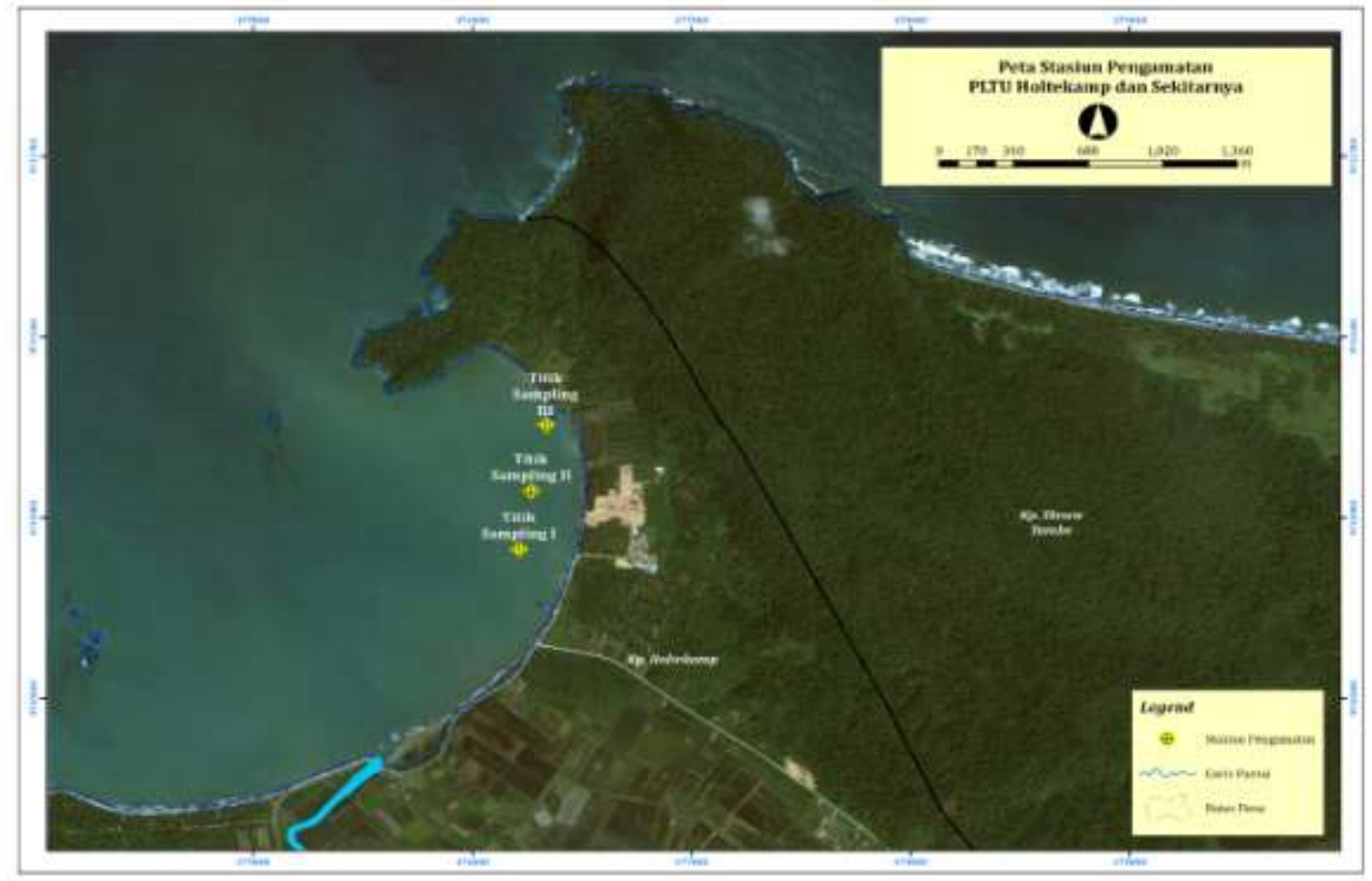

Gambar 1. Peta Stasiun Pengambilan Sampel Penelitian (Citra landsat 8, 2013)

\section{Pengamatan dan Analisis Sampel}

Identifikasi fitoplankton, dilakukan berdasarkan karakteristik morfologi (bentuk tubuh fitoplankton) yang dicocokkan dengan referensi "Planktonology" (Sachlan, 1972), "Identifying Marine Phytoplankton" (Thomas, 1997), "Phytoplankton Identification Cataloge" (Botes, 2003), dan "Plankton Laut" oleh (Nontji, 2008). Kelimpahan fitoplankton dihitung berdasarkan metoda sapuan di atas Sedgwick Rafter Counting Cell (SRCC). Kelimpahan plankton dinyatakan secara kuantitatif dalam jumlah ind/liter. Perhitungan dengan menggunakan rumus modifikasi "Lackey Drop Micro Transect Counting Method" 1976 (Syafara, 1996).

$$
\mathrm{F}=\frac{T}{L} \times \frac{V o}{V 1} \times \frac{1}{p} \times \frac{1}{w}
$$

dimana :

$\mathrm{F} \quad$ = frekuensi individu yang ditemukan

$\mathrm{T}=$ luas gelas penutup $\left(18 \times 18 \mathrm{~mm}^{2}\right)$

$\mathrm{L} \quad=$ luas lapang pandang mikroskop 
$\mathrm{V}_{0} \quad=$ volume individu dalam botol penampung $(20 \mathrm{ml})$

$\mathrm{V}_{1} \quad=$ volume individu di bawah gelas penutup $(0,15 \mathrm{ml})$

$\mathrm{p} \quad=$ jumlah lapang pandang yang diamati (3 kali)

$\mathrm{w} \quad=$ volume air yang disaring $(100 \mathrm{l})$

Jumlah individu per liter $=\mathrm{F} \times \mathrm{N}$

dimana: $\mathrm{N} \quad$ = jumlah individu yang ditemukan pada tiap preparat

Untuk menghitung Indeks keanekaragaman, dihitung menggunakan rumus ShannonWiener (Romimohtarto \& Juwana, 2009).

dimana :

$$
\mathrm{H}^{\prime}=-\sum P i \ln P i \quad \mathrm{Pi}=\frac{n i}{N}
$$

$\mathrm{H}^{\prime} \quad=$ Indeks keanekaragaman jenis

$\mathrm{N} \quad=$ Jumlah total individu

ni = Jumlah individu suatu jenis

$\mathrm{Pi} \quad=$ Jumlah individu dalam satu jenis per jumlah total individu

Kriteria :

$\mathrm{H}^{\prime}<1=$ Keanekaragaman rendah

$1<\mathrm{H}^{\prime}<3=$ Keanekaragaman sedang

$\mathrm{H}^{\prime}>3=$ Keanekaragaman tinggi

Indeks dominasi dihitung dengan rumus (Odum, 1996; Romimohtarto \& Juwana, 2009).

dimana :

$$
\mathrm{C}=\sum(P i)^{2}=\left(\frac{n i}{N}\right)^{2}
$$

C = Indeks Dominasi

ni = Jumlah individu suatu jenis

$\mathrm{N} \quad=$ Jumlah total individu

$\mathrm{Pi} \quad=$ Jumlah individu dalam satu jenis per jumlah total individu

Dari kedua nilai $\mathrm{H}^{\prime}$ dan $\mathrm{C}$ memberikan gambaran bahwa semakin tinggi nilai $\mathrm{H}^{\prime}$ maka keragaman spesies perairan yang diteliti semakin tinggi. Sedangkan untuk nilai indeks Dominansi (C), semakin tinggi nilai $\mathrm{C}$ akan semakin tinggi pula keseragaman populasi, dimana jumlah individu setiap spesies dapat dikatakan sama.

\section{HASIL DAN PEMBAHASAN}

\section{Komposisi dan Kelimpahan Fitoplankton}

Berdasarkan hasil penelitian, hasil identifikasi, komposisi genera fitoplankton yang ditemukan dapat dilihat pada Tabel 1. Hasil identifikasi menunjukkan terdapat 17 genus yang berasal dari 2 kelompok fitoplankton yaitu Diatomae 14 genus dan Dinoflagellata 3 genus. Jumlah genus dari setiap stasiun pengamatan adalah genus dengan total rata-rata kelimpahan 1916,67 ind/l. Jumlah kelimpahan tertinggi ditemukan pada stasiun 3 (15 genus) dan total kelimpahan yaitu 2655 ind/l, sedangkan jumlah genus terendah terdapat pada stasiun 2 yaitu 15 genus dengan jumlah kelimpahan rata-rata 705 ind/l (Tabel 1). Rendahnya total kelimpahan pada stasiun 2 disebabkan lokasi stasiun yang terletak di dekat PLTU Holtekamp, sebagaimana yang dijelaskan oleh Kamilah, dkk., (2014) bahwa perairan disekitar 
pelabuhan memiliki kualitas yang tidak begitu baik, sehingga hanya dapat dihuni oleh marga-marga yang toleran terhadap pencemaran.

Tabel 1. Komposisi dan rata-rata kelimpahan fitoplankton (Ind/l) pada tiap stasiun di Perairan PLTU Holtekamp.

\begin{tabular}{|c|c|c|c|c|c|c|}
\hline \multirow[t]{2}{*}{ No } & \multirow[t]{2}{*}{ Kelas } & \multirow[t]{2}{*}{ Genus } & \multicolumn{3}{|c|}{ Lokasi Sampling } & \multirow[t]{2}{*}{ Rata-rata } \\
\hline & & & 1 & 2 & 3 & \\
\hline \multicolumn{7}{|c|}{ Diatomae } \\
\hline 1 & Bacillariophyceae & Bacteriastrum & 520 & 125 & 850 & 498,33 \\
\hline 2 & & Cerratulina & 1015 & 310 & 1010 & 778,33 \\
\hline 3 & & Chaetoceros & 90 & 20 & 105 & 71,67 \\
\hline 4 & & Coscinodiscus & 290 & 70 & 525 & 295 \\
\hline 5 & & Nitzchia & 75 & 30 & 65 & 56,67 \\
\hline 6 & & Pleurosigma & 40 & 15 & & \\
\hline 7 & & Rhizosolenia & 35 & & 15 & \\
\hline 8 & & Thalassiosira & 45 & 10 & 15 & 23,33 \\
\hline 9 & & Thalassionema & & 35 & 10 & 22,5 \\
\hline 10 & Chlorophyceae & Chlorococcum & 25 & 5 & 15 & 15 \\
\hline 11 & & Schroederia & 105 & 35 & 10 & 50 \\
\hline 12 & & Spaeroplea & 20 & 15 & 5 & 13,33 \\
\hline 13 & Cyanophyceae & Microcoleus & 5 & 5 & 5 & 5 \\
\hline 14 & & Oscillatoria & 5 & 10 & 15 & 10 \\
\hline \multicolumn{7}{|c|}{ Dinoflagellata } \\
\hline 15 & Dinophyceae & Cerratium & & 5 & 5 & 5 \\
\hline 16 & & Gonyaulax & 25 & 15 & 5 & 15 \\
\hline 17 & & Protoperidinium & 5 & & & 5 \\
\hline \multicolumn{3}{|c|}{ Kelimpahan (Ind/I) } & 2300 & 705 & 2655 & 1916,67 \\
\hline
\end{tabular}

Banyaknya diatom dan dinoflagleata di perairan sekitar PLTU sejalan dengan penelitian terdahulu yaitu didominasi Diatom dan dinoflagelata, seperti di Pulau Bonerate, Sulawesi Selatan ditemukan 52 genus Diatom, 21 genus Dinoflagellata dan 7 genus Cyanophyceae (Erwin, dkk., 2005). Dominasi dinoflagelata dan diatom diduga karena fitoplankton yang termasuk dalam kelas ini mempunyai adaptasi yang tinggi dan mampu hidup pada berbagai kondisi perairan termasuk kondisi ekstrim. Menurut Odum (1998), banyaknya kelas Bacillariophyceae (Diatom) di perairan disebabkan oleh kemampuannya beradaptasi dengan lingkungan, bersifat kosmopolit, tahan terhadap kondisi ekstrim serta mempunyai daya reproduksi yang tinggi. Amedia (2013), menyatakan bahwa pada saat terjadi peningkatan konsentrasi zat hara, diatom mampu melakukan reproduksi sebanyak tiga kali dalam 24 jam, sedangkan dinoflagellata hanya mampu melakukannya satu kali dalam 24 jam pada kondisi zat hara yang sama.

Berdasakan stasiun yang telah ditetapkan, masing-masing stasiun I, stasiun II dan stasiun III dominasi fitoplankton yaitu lebih besar dari 94\% berasal dari kelas Bacillariophyceae (Diatom). Sedangkan Chlorophyceae 4\% dan Cyanophyceae dan Dinophyceae masing-masing 1\%. Dominasi Bacillariophyceae (Diatom) diduga disebabkan terjadinya fluktuatif di perairan Holtekamp cukup tinggi, karena merupakan daerah yang sibuk dengan aktivitas opraisional PLTU, daerah tangkapan nelayan, dan daerah wisata. Kawasan ini juga banyak mendapatkan input nutrient yang berasal dari aliran sungai berada di sekitar lokasi ini. Fitoplankton dari kelas Bacillariophyceae (Diatom) mempunyai respon yang sangat cepat terhadap penambahan nutrient dan mampu beradaptasi dengan lingkungan tempat hidupnya dibandingkan dengan genera dari kelas yang lainnya (Lagus, 2004: Nybakken, 2005). 


\section{Indeks Keragaman dan Dominansi}

Nilai indeks keragaman $\left(\mathrm{H}^{\prime}\right)$, dan indeks Dominansi $(\mathrm{C})$ fitoplankton dari ketiga stasiun sampling di perairan Holtekamp disajikan pada Tabel 2.

Tabel 2. Kelimpahan fitoplankton, indeks keragaman ( $\left.\mathrm{H}^{\prime}\right)$, dan indeks Dominansi (D) di perairan Holtekamp

\begin{tabular}{ccc}
\hline Titik Pengambilan Sampel & Keanekaragaman (H') & Dominasi (D) \\
\hline Stasiun 1 & 1,73 & 0,27 \\
Stasiun 2 & 1,90 & 0,24 \\
Stasiun 3 & 1,48 & 0,28 \\
\hline
\end{tabular}

Tabel 2 menunjukkan bahwa indeks keragaman fitoplankton berkisar antara 1,48-1,90. Nilai indeks keragaman tertinggi $\left(\mathrm{H}^{\prime}\right)$ dijumpai pada stasiun $2(1,90)$ dan terendah pada stasiun $1(1,73)$. Indeks dominansi pada ketiga stasiun berkisar 0,240,28 . Hal ini menunjukan bahwa pada ketiga stasiun tersebut tidak terdapat spesies yang dominan. Penentuan nilai indeks dominansi (C) adalah dengan cara metode perhitungan dengan rumus indeks dominansi Simpson dengan ketentuan jika nilai indeks dominansi $0<\mathrm{C} \leq 0,5$ maka tidak ada genus yang mendominasi dan jika nilai indeks dominansi $0,5<\mathrm{C}<1$ maka terdapat genus yang mendominasi. Hal ini diperkuat oleh Pirzan \& Rani (2008) apabila nilai dominansi mendekati nilai 1 berarti di dalam komunitas terdapat genus yang mendominansi genus lainnya, sebaliknya apabila mendekati nilai 0 berarti di dalam struktur komunitas tidak terdapat genus yang secara ekstrim mendominasi genus lainnya.

Adanya perbedaan nilai indeks keragaman dan dominansi disebabkan oleh faktor fisika air serta ketersediaan nutrisi dan pemanfaatan nutrisi yang berbeda dari tiap individu. Faktor-faktor yang mempengaruhi nilai indeks keanekaragaman dan dominansi dapat berasal dari faktor lingkungan yaitu ketersediaan nutrisi seperti phospat dan nitrat, serta kemampuan dari masing-masing jenis fitoplankton untuk beradaptasi dengan lingkungan yang ada (Hamuna, dkk., 2019).

Indeks keanekaragaman termasuk dalam kategori sedang karena nilai berada pada rentang $1<\mathrm{H}^{\prime}<3$. Kondisi ini menunjukkan bahwa produktivitasnya rendah, kondisi ekosistem tidak stabil, dan tekanan ekologi yang tinggi (Carong, 2011). Hal ini juga bisa di sebabkan oleh aktivitas PLTU Holtekamp yang saat ini sedang beroperasi. Pada hasil penelitian terdapat populasi dari genus Coscinodiscus, Cerratulina, dan Ceratium yang ditemukan pada ketiga stasiun dengan kelimpahan sedang sampai besar, dengan kehadiran genus tersebut pada satu perairan akan dapat mempengaruhi keseimbangan populasi dalam suatu komunitas (Carong, 2011). Genus-genus ini banyak ditemukan di perairan Indonesia dan dikategorikan ke dalam fitoplankton penyebab HAB (Harmfull Algae Bloom) yang menimbulkan gangguan ekosistem perairan dan juga kesehatan pada manusia (GEOHAB, 2001)

Indeks keanekaragaman pada setiap stasiun tergolong dalam kategori sedang hal ini diduga karena indeks keragaman tiap stasiun pun sedang, hal ini mengisyaratkan tidak adanya dominasi suatu spesies terhadap spesies lain. Dominasi yang rendah akan mengarah pada komunitas yang stabil.

\section{Parameter lingkungan}

Hasil pengukuran parameter lingkungan di perairan Holtekamp, meliputi kadar $\mathrm{O}_{2}, \mathrm{pH}$, suhu, salinitas, nitrat, phospat, dan kekeruhan tertera pada Tabel 3 . Kandungan $\mathrm{O}_{2}$ pada perairan Holtekamp relatif sama yang berkisar antara 7,77-7,87 
$\mathrm{mg} / \mathrm{L}$. Kadar oksigen terlarut rata-rata 7,8 mg/L, kadar ini tergolong tinggi. Menurut Suryanti (2013) menyatakan bahwa kehidupan di air masih dapat bertahan jika ada oksigen terlarut minimum sebesar $5 \mathrm{mg} / \mathrm{L}$, yang berarti kadar $\mathrm{O}_{2}$ terlarut di setiap stasiun pengamatan masih dapat mendukung kehidupan di perairan tersebut.

Tabel 3. Parameter Lingkungan DO $(\mathrm{mg} / \mathrm{L}), \mathrm{pH}$, Suhu $\left({ }^{\circ} \mathrm{C}\right)$, dan Salinitas $(\mathrm{ppm}) \mathrm{di}$ Perairan Holtekamp.

\begin{tabular}{cccc}
\hline \multirow{2}{*}{ PARAMETER AIR } & \multicolumn{3}{c}{ HASIL PENGUKURAN } \\
\cline { 2 - 4 } & Stasiun 1 & Stasiun 2 & Stasiun 3 \\
\hline DO (ppm) & 7,77 & 7,8 & 7,87 \\
pH & 7,77 & 7,83 & 7,93 \\
Salinitas (\%) & 32 & 31,7 & 32 \\
Kecerahan (m) & 4,12 & 4,13 & 4,1 \\
Suhu ( $\left.{ }^{\circ} \mathrm{C}\right)$ & 29 & 29,4 & 29,7 \\
Kecepatan Arus (m/s) & 0,097 & 0,098 & 0,099 \\
\hline
\end{tabular}

Nilai pH pada ketiga stasiun berkisar 7,77-7,93, hal ini menunjukkan bahwa kadar pH di perairan pesisir Holtekamp masih berada di kisaran normal. Erari, dkk (2012), memperoleh data pH perairan Teluk Youtefa yang berkisar antara 6,28-8,7 di bagian laut dan 7,25-7,76 di perairan dekat muara sungai serta Silalahi, dkk., (2017) yang mendapatkan $\mathrm{pH}$ perairan Maruni Manokwari berkisar antara 7-8,3. Menurut Dojlido \& Best (1993), bahwa pH air laut relatif lebih stabil dan biasanya berada dalam kisaran 7,5 dan 8,4, kecuali dekat pantai. Nilai pH yang ideal bagi perairan adalah 7-8,5 (Hamuna, 2018). Kondisi perairan yang sangat basa maupun sangat asam akan membahayakan kelangsungan hidup organisme karena akan mengganggu proses metabolisme dan respirasi (Hamuna, 2018).

Sebaran salinitas di perairan Holtekamp berkisar antara 31,7-32\%o. Menurut Tarigan \& Edward (2003), salinitas di perairan Indonesia pada umumnya berkisar antara 30-35\%o, sedangkan untuk laut terbuka salinitasnya $>34 \%$. Salinitas di perairan Holtekamp masih sesuai dengan kisaran salinitas pada umumnya di perairan Indonesia.

Tingkat kecerahan air di ketiga stasiun sampling di perairan Holtekamp, dapat dilihat pada Tabel 3. Tingkat kecerahan air berkisar antara 4,1-4,14 m. Hamuna, (2018), menyebutkan kecerahan yang tinggi menunjukkan daya tembus cahaya matahari yang jauh ke dalam perairan, begitu pula sebaliknya, dalam hal ini adalah jarak tembus cahaya kedalam suatu perairan. Kecerahan di perairan tersebut termasuk dalam kisaran baik untuk kehidupan fitoplankton karena lebih dari $3 \mathrm{~m}$. Berdasarkan Keputusan Menteri Lingkungan Hidup no. 51 tahun 2004, batas kecerahan dari ekosistem terumbu karang adalah $>5 \mathrm{~m}$, dan untuk ekosistem lamun $>3 \mathrm{~m}$. Kecerahan sangat bergantung pada tinggi rendahnya intesitas cahaya, rendahnya intensitas dapat menyebabkan tingginya jumlah kelimpahan fitoplankton pada perairan, karena untuk melakukan sintesa klorofil yang efektif umumnya diperlukan intensitas cahaya yang relatif rendah. Cahaya yang intensitasnya terlalu kuat akan merusak klorofil dalam reaksi yang disebut photo oxidation (Widiadmoko, 2013).

Suhu sangat mempengaruhi kehidupan organisme dan kondisi perairan. Perubahan suhu berpengaruh terhadap proses fisika dan kimia di badan air. Suhu juga sangat berperan mengendalikan kondisi ekosistem perairan (Kusumaningtyas, dkk. 2014).). Suhu di perairan Holtekamp adalah sekitar $29^{\circ}-29,7^{\circ} \mathrm{C}$. Suhu perairan Holtekamp masih berada dalam kisaran suhu optimum dimana fitoplankton dapat 
hidup dengan baik. Menurut (Kusumaningtyas, dkk., 2014).), kisaran suhu optimum bagi pertumbuhan fitoplankton di perairan adalah $20^{\circ}-30^{\circ} \mathrm{C}$. Massa air permukaan di wilayah tropik, panas sepanjang tahun, yaitu $20^{\circ}-30^{\circ} \mathrm{C}$ (Nybakken, 1992).

Hasil pengukuran kecepatan arus yang dilakukan mendapatkan nilai sekitar 0,097-0,099 m/s. Kecepatan arus di perairan tersebut termasuk kategori arus laut kuat, arus yang kuat akan mempercepat persebaran organisme terhanyut. Perpindahan massa air atau arus berperan dalam proses persebaran fitoplankton dan organisme lain yang ada di perairan. Hal ini sesuai dengan Nybakken (1992), kemampuan berenang organisme planktonik sangat lemah sehingga pergerakannya hanya mengikuti arus air. Gerakan air laut ini sangat penting bagi berbagai proses alam laut, baik itu bagi makhluk hidup atau tak hidup (Hamuna, 2018).

Kadar fosfat pada setiap stasiun berkisar antara 0,48-0.58 mg/L, kadar fosfat di perairan ini, relatif tinggi dibandingkan dengan kandungan fosfat dalam perairan laut normal. Menurut Efendi (2003), air laut normal memiliki kadar rata-rata kandungan fosfat berkisar $0,002 \mathrm{mg} / \mathrm{L}$. Diduga konsentrasi fosfat tinggi karena dekatnya perairan dari sumber masukan fosfat dari daratan. Pengaruh daratan terhadap masukan fosfat ke perairan tersebut terlihat sangat besar. Selain secara alami, sumber fosfat di perairan Holtekam diduga berasal dari aktifitas manusia, seperti buangan limbah domestik, aktifitas PLTU dan kegiatan lainnya serta limpahan air dari aktifitas pertanian masyarakat yang telah berlangsung dalam waktu yang lama. Menurut Affan (2010) bahwa senyawa fosfat di perairan berasal dari sumber alami seperti erosi tanah, buangan dari hewan dan pelapukan tumbuhan. Konsentrasi meningkat dengan masuknya limbah domestik, industri dan pertanian atau perkebunan yang banyak mengandung fosfat, hancuran bahan organik dan mineralmineral fosfat.

Kadar nitrat pada ketiga stasiun berkisar 0,021-0,041 mg/L. Menurut Efendi (2003) dalam Hamuna B. (2018), kadar nitrat dalam perairan alami hampir tidak pernah lebih dari 0,1 mg/L, serta pendapat Budihardjo \& Haryono (2007), kadar nitrat dalam perairan yang disebabkan oleh pencemaran dari aktifitas penduduk berkisar antara $0-0,2 \mathrm{mg} / \mathrm{L}$.

Perbandingan nitrat : phospat pada tiap stasiun menunjukkan kadar nitrat lebih rendah dari kadar phospat. Menurut Hamuna, (2018), ratio perbandingan N : P yang baik untuk pertumbuhan fitoplankton yaitu Nitrat harus lebih tingginggi dibandingkan phospat. Dengan demikian perbandingan N : P pada perairan ini tidak sesuai dengan standar perairan normal. Sehingga perbandingan N : P pada perairan ini termasuk mengkhawatirkan atau tidak sesuai dengan standar perairan normal.

Tabel 4. Parameter lingkungan Nitrat dan Fosfat di perairan Holtekamp

\begin{tabular}{lccc}
\hline \multirow{2}{*}{ PARAMETER AIR } & \multicolumn{3}{c}{ HASIL PENGUKURAN } \\
\cline { 2 - 4 } & Stasiun 1 & Stasiun 2 & Stasiun 3 \\
\hline Nitrat $(\mathrm{ml} / \mathrm{l})$ & 0,021 & 0,041 & 0,036 \\
Fosfat $(\mathrm{mg} / \mathrm{l})$ & 0,54 & 0,48 & 0,58 \\
\hline
\end{tabular}

Meskipun kadar nitrat yang terdapat di lokasi penelitian memiliki kadar yang rendah tetapi dengan keberadaannya bersama phospat yang memiliki kadar sangat tinggi dapat mengakibatkan tumbuhnya alga atau fitoplankton potensial berbahaya dan kekurangan $\mathrm{O}_{2}$ dalam air (Apriliana, dkk., 2014).

Hal ini terlihat pada Tabel 1, terlihat kelimpahan tertinggi ada pada genus Cerratulina yang merupakan salah satu alga yang berpotensi berbahaya, yang mana 
jika Cerratulina mengalami blooming dapat mengakibatkan berkurangnya kadar $\mathrm{O}_{2}$ pada perairan tersebut yang dapat menyebabkan kematian massal organismelaut (Mulyani, 2012).

\section{KESIMPULAN}

Berdasarkan hasil penelitian, dapat disimpulkan bahwa fitoplankton yang ditemukan pada perairan Holtekamp Kota Jayapura sebanyak 17 genus dengan kelimpahan rata-rata tertinggi yaitu dari genus Cerratulina (1015 ind/L) dan nilai kelimpahan terendah adalah dari genus Protoperidinium (rata-rata 5 ind/L). Indeks keanekaragaman termasuk dalam kategori keanekaragaman sedang (1,48-1,90). Indeks dominansi berkisar antara 0,24-0,28 atau dominansinya rendah.

\section{REFERENSI}

Amedia, I. (2013). Diatome sebagai bioindikator Air. Semarang: Universitas Diponegoro.

Apriana, R., Rusdiyanti,, S., \& Purnomo, , P. (2014). Keanegaragaman jenis bakteri perairan dasar berdasarkan tipe tutupan permukaan perairan di Rawa Pening. Diponegoro Journal of Maquares, 3 (2): 119-128.

Brotowidjoyo, T. M., \& E., M. (1995). Pengantar Perairan dan Budidaya Air. Yogyakarta: Liberty Yogyakarta.

Budiharjo, M., \& Haryono, H. S. (2007). Pola persebaran Nitrat dan Phospat dengan Model Aquatox2.2 serta Hubungan Terhadap Eceng Gondok pada Permukaan Danau (Studi Kasus Danau Rawa Pening kabupaten Semarang). Presipitasi, 3 (2) : 58-66.

Carong, S. (2011). Struktur Komunitas Ikan di Perairan Pantai Kabupaten Mimika Provinsi Papua Indonesia. Makassar: Skripsi Jurusan Biologi Universitas Hasanuddin .

Davis, M., \& D.A., C. (1991). Introduction to Enviromental Engineering Second Edition. New York: Mc-Graw-Hill, Inc.

Dojlido, J., \& Best, G. (1993). Chemistry of Water Population. England: Ellis Horwood Ltd.

Effendi, H. (2003). Telaah Kualitas Air bagi pengelolaan Sumberdaya dan Lingkungan Perairan. Yogyakarta: Kanisius.

Erari, S., Mangimbulude, J., \& Lewerissa, K. (2012). Pencemaran Organik di Perairan Pesisir Pantai Teluk Youtefa Kota Jayapura, Papua. Seminar Nasional Kimia Unesa (pp. C327C340). Surabaya: Seminar Nasional Kimia 2012.

Fachrul, M., \& H. Haeruman, S. L. (2005). Komunitas Fitoplankton sebagai Bioindikasi Kualitas Perairan teluk Jakarta. Jakarta: FMIPA.

Hamuna, B., Tanjung, H. R., Suwito, Maury, H., \& Alianto. (2018). Kajian Kualitas Air Laut dan Indeks Pencemaran Berdasarkan Paramater Fisika-Kimia di Perairan Depapre, Jayapura. Jurnal Ilmu Lingkungan, 16 (1) : 35-43.

Hutagalung, H., D., S., \& S. H., R. (1997). Metode Analisis Air Laut, Sedimen dan Biota. Buku 2. Jakarta: Puslitbang Oseanologi LIPI.

Hutomo, M., \& O. H. , A. (1992). Dampak Pembangkit Tenaga Listrik (Terutama Limbah Termal) Terhadap Ekosistem Akuatik. Jurnal Oseana, 17 (4) : 135-158.

Kamilah , F., Rachmadiarti, F., \& Indah, K. N. (2014). Keanekaragaman Plankton Yang Toleran terhadap Kondisi Perairan Tercemar di Sumber Air Belerang, Sumber Beceng Sumenep, Madura. Jurnal Lenterabio, 3 (3) : 226-231. 
Keputusan Menteri Lingkungan Hidup. (2014). Lampiran III Keputusan Meneteri Negera Lingkungan Hidup No. 51 Tahun 2004. Baku Mutu Air Laut untuk Biota Laut. Jakarta: Kementerian Negera Lingkungan Hidup.

Kusumaningtyas, M., Bramawanto, R., Daulat , A., \& Pranowo, W. (2014). Kualitas perairan Natuna pada Musim Transisi. Depik, 3 (1) : 10-20.

Millero, F., \& M.L., S. (1991). Chemical Oseanografi. London: CRC Press.

Mulyani, R. W., \& W., W. (2012). Sebaran Spasial Spesies Penyebab Harmful Algae Bloom (HAB) di Lokasi Budidaya Karang Hijau Kanal Muara Jakarta Utara pada Bulan Mei 2011. Jurnal Akuatika, 3 (1) : 28-39.

Nontji. (2008). Planton Laut. Jakarta: LIPI Press.

Nybakken, J. (1992). Niologi Laut; Suatu Pendekatan Ekologis, Terjemahan. Jakarta: Gramedia Pustaka Utama.

Odum, E. (1996). Dasar-dasar Ekologi. Yogyakarta: Gajah Mada university Press.

Riyono, S. (2007). Beberapa Sifat Umum dari Klorofil Fitoplankton. Oseana, 32 (1) : 23-31.

Romimoharto, K., \& Sri , J. (2009). Biologi Laut. Jakarta: Djambatan.

Sachlan, M. (1982). Planktonologi. Semarang: FPP, Universitas Diponegoro.

Sastrawijaya, A. (1991). Pencemacarn Lingkungan. Jakarta: Rineka Cipta.

Silalahi, H., Manaf, M., \& Alianto. (2017). Status Mutu Kualitas Air Laut Pantai Maruni Kabupaten Manokwari. Jurnal Sumberdaya Akuatik Indopasifik, 1 (1) : 33-42.

Soedibjo, B. (2006). Struktur Komunitas Fitoplankton dan Hubungannya dengan Beberapa Parameter di Lingkungan Teluk Jakarta. Oseonologi dan Limnologi di Indonesia, 40 (3) : 65-78.

Sunarto. (2008). Karakteristik Biologi dan penaranan Plankton bagi Ekosistem Laut. Jatinangor: FPIP, Universitas Padjadjaran.

Suryani, S., Rudiyanti, \& Sumartini, S. (2013). Kualitas Perairan Sungai Seketak Semarang Berdasarkan Komponsisi dan Kelimpahan Fitoplankton. Journal of Management of Aquatic Resorces, 2 (2) : 38-45.

Syafara, Z. (1996). Kelimpahan dan Keanekaragaman Fitoplankton di Perairan Pantai Trikora, Pulau Bintan. Jurnal Penelitian Perikanan Indonesia, 2 (1) : 1-10.

Tarigan, M., \& Edward. (2012). Kondisi Hidrologi Perairan Teluk Kao, Pulau Halmahera Maluku Utara. Ekosistem Pesisir Ternate, Tidore (pp. 19-23). Jakarta: Pusat Penelitian Oseanografi, LIPI Jakarta.

Widiadmoko, W. (2013). Pemantauan Kualitas Air Secara Fisika dan Kimia di Perairan Teluk Hurun., Bandar Lampung. Lampung: Balai Besar Pengembangan Budidaya Laut (BBPBL)

Wijaya, T., \& Riche, H. (2011). Struktur Komunitas Fitoplankton sebagai Bioindikator Kualitas Perairan Danau Rawa Pening Kabupaten Semarang Jawa Tengah. Jurnal Anatomi Fisiologi Semarang, 19 (1) : 55-61.

Yuliana, Enan, M., Enang , H., \& Niken, T. (2012). Hubungan antara Kelimpahan Fitoplankton dengan Parameter Fisik Kimiawi Perairan Teluk Jakarta . Jurnal Akuatik (3) 2, 169179. 